University of Nebraska - Lincoln

DigitalCommons@University of Nebraska - Lincoln

Faculty Publications, UNL Libraries

Libraries at University of Nebraska-Lincoln

2008

\title{
Library Personnel's Role in the Creation of Metadata: A Survey of Academic Libraries
}

\author{
Adonna Fleming \\ University of Nebraska - Lincoln, dfleming2@unl.edu \\ Margaret Mering \\ University of Nebraska - Lincoln, mmering1@unl.edu \\ Judith A. Wolfe \\ University of Nebraska-Lincoln, jwolfe4@unl.edu
}

Follow this and additional works at: https://digitalcommons.unl.edu/libraryscience

Part of the Library and Information Science Commons

Fleming, Adonna; Mering, Margaret; and Wolfe, Judith A., "Library Personnel's Role in the Creation of Metadata: A Survey of Academic Libraries" (2008). Faculty Publications, UNL Libraries. 222.

https://digitalcommons.unl.edu/libraryscience/222

This Article is brought to you for free and open access by the Libraries at University of Nebraska-Lincoln at DigitalCommons@University of Nebraska - Lincoln. It has been accepted for inclusion in Faculty Publications, UNL Libraries by an authorized administrator of DigitalCommons@University of Nebraska - Lincoln. 


\title{
Library Personnel's Role in the Creation of Metadata: A Survey of Academic Libraries
}

\author{
Adonna Fleming \\ Margaret Mering \\ Judith A. Wolfe
}

\begin{abstract}
The digital age has caused the paradigm to shift in academic libraries both in terms of their collections and the roles of their personnel. As academic libraries begin to digitize objects in their collections, how and who in the library creates access to these resources has become a hot issue.

At the University of Nebraska-Lincoln Libraries (UNL Libraries), taskforces were formed to study metadata schemes used at UNL Libraries. The taskforces identified the various metadata schemes in use and the role of various departments within UNL Libraries in the creation of metadata. They made recommendations about how to document decisions relating to metadata and how to coordinate metadata creation and digitization projects. As a result, the authors decided to survey American Research Libraries (ARL) and other peer libraries to determine their metadata workflow.
\end{abstract}

Adonna Fleming, MLS, is GIS-Maps-Geosciences Librarian/Associate Professor, University of Nebraska-Lincoln, Geology Library, 10 Bessey Hall, Lincoln, NE 68588-0344 (E-mail: dfleming2@unl.edu).

Margaret Mering, MLS, is Principal Serials Catalog and Metadata Librarian/ Professor, University of Nebraska-Lincoln, 322 Love Library, P.O. Box 884100, Lincoln, NE 68588-4100 (E-mail: mmering1@unl.edu).

Judith A. Wolfe, MLIS, is Catalog and Metadata Librarian/Assistant Professor, University of Nebraska-Lincoln, 322 Love Library, P.O. Box 884100 Lincoln, NE 68588-4100 (E-mail: jwolf1@unlnotes.unl.edu).

Technical Services Quarterly, Vol. 25(4) 2008

Available online at http://tsq.haworthpress.com

(c) 2008 by The Haworth Press. All rights reserved. doi:10.1080/07317130802127983 
This paper discusses the results of the survey and provides insight as to how libraries may meet the challenge of creating metadata through the reorganization of departments and staffing responsibilities.

KEYWORDS. Metadata, workflow, cataloging, digital projects, technical services

In the past, catalog librarians and the technical services department staff were chiefly responsible for the creation and maintenance of records in the library's catalog that provided information about the collections. Records for online catalogs were mostly created using MARC and Anglo-American Cataloguing Rules (AACR2). Today, a variety of schemas in addition to MARC (e.g., Dublin Core, EAD, and MODS) are used. These schemas are generally referred to as metadata, which is best described as "formally structured documentation of digital data that describes the who, what, when, why and how of every aspect of the data."1

Today the creation of metadata records is no longer solely the purview of technical services. The information explosion and the digital age are driving forces behind this redistribution of metadata work responsibilities. Libraries are no longer catalog-centric, and their Web pages are a gateway to many information resources in addition to their own physical holdings.

The information explosion, in terms of libraries, has been about forty years in the making. From the 1960s, beginning with online systems such as DIALOG, through the 1980s and the emergence of Online Public Access Catalogs (OPACs), libraries were able to control access to information resources. With the advent of the World Wide Web and the ease of using Internet search engines, however, end users were able to surpass the mediated search for direct access, and libraries became one of many resources of information. ${ }^{2}$

The School of Information Management and Systems at the University of California-Berkeley studied how much new information was created between 1999 and 2002, concluding there were about five exabytes of new information created in 2002, which doubled that created in 1999. The study projected that new information will grow at a rate of 30 percent annually. Most of this new information is stored on magnetic tape-in other words, digitally. The study explains that five 
exabytes of information, if digitized, would be the equivalent of 37,000 new libraries, each the size of the Library of Congress book collection. ${ }^{3}$

Faced with the explosion of information, the availability of technology to create digital copies of print materials, and the scarcity of catalog librarians in the job market, academic libraries have had no choice but to realign work responsibilities for creating and maintaining metadata. They moved from the traditional catalog-centric model to a more distributed model involving multiple departments within the library.

\section{LITERATURE REVIEW}

Redistribution of metadata work assignments has been discussed extensively in the literature. Sylvia D. Hall-Ellis, in her article "Cataloging Electronic Resources and Metadata: Employers' Expectations as Reflected in American Libraries and AutoCat, 2000-2005," discussed the results of a survey she conducted using job advertisements to determine employer expectations of recent library school graduates. She determined that employers expect entry-level catalogers to be familiar with several metadata schemes. She also noted that there was no longer a distinction between entry-level catalog librarians and paraprofessional co-workers when it came to the creation of original bibliographic records. ${ }^{4}$ This redistribution of work responsibilities also carries over into the creation and documentation of standards. Newer metadata standards are being developed in various disciplines and are in direct competition to traditional cataloging standards, such as AACR2. 5

Two articles, one by Jeanne M. K. Boydston and Joan M. Leysen and the other by Stanley J. Wilder, refer to the shrinking number of personnel in catalog departments in the face of increased workload. Wilder noted a 46 percent decrease in the hiring of cataloging professionals between 1983 and 2000. ${ }^{6}$ Boydston and Leysen argued that hiring reductions and advances in technology are the main causes of shrinking catalog departments, and that paraprofessionals have taken up the slack. ${ }^{7}$

The authors' survey of ARL and other selected libraries supported this change in cataloging department staffing and work responsibilities for the creation of non-MARC metadata. According to survey responses, 27 of 39 participating libraries indicated that this responsibility has been dispersed throughout departments within the library. Non-MARC metadata is created by non-cataloging librarians and paraprofessionals from other departments as well as those who work in technical services. 
Eleven of those responding indicated that non-MARC metadata is created completely outside of technical services. None of the libraries reported having non-MARC metadata created solely outside the library; however, 11 libraries reported having non-MARC metadata created by units outside the library in addition to technical service and other library departments.

\section{METHODOLOGY}

At the UNL Libraries, taskforces were formed to study metadata schemes used at the Libraries. One taskforce identified the multiple metadata schemes used to search and access information and digital content. Other taskforces explored the metadata roles of various departments within the Libraries. The taskforces made recommendations on how to document decisions relating to metadata and how to coordinate metadata creation and digitization projects. As a result, the authors decided to survey ARL and other peer libraries to determine their metadata workflow, with a particular interest in how libraries are meeting the challenge of creating metadata through the reorganization of departments and staffing responsibilities.

Population. The investigation originally targeted 36 libraries, which included the University of Nebraska-Lincoln's peer institution libraries and Greater Western Library Alliance libraries. Later, ARL academic institutions whose primary language is English were added. At least one academic library from each state was represented in the survey's population. The final target population was 129 possible respondents.

Survey. The survey was created in two formats: a Microsoft Word document and an online version. The online survey was created using CTL Silhouette/Flashlight Online. Both formats of the survey included seven sections. The printed survey had a total of 19 questions. The online survey format, because of software restrictions, divided multipart questions into separate questions. The online survey had 37 questions. Participants had a choice of which format they wanted to use. The survey and corresponding documents were reviewed by the Institutional Review Board (IRB) at University of Nebraska-Lincoln, and mailed to participants in March 2007. A follow-up e-mail reminder was sent in April 2007. 


\section{SURVEY SUMMARY}

The focus of the survey was to study the division and distribution of work assignments involved in creating and maintaining of metadata, particularly what departments and level of staff outside of technical services had metadata-related assignments.

Forty-six responses to the survey were received, 36 percent of the survey population. Forty respondents were from ARL libraries; 42 represented universities in 28 states and Washington, D.C. Four Canadian universities also responded to the survey.

The survey consisted of seven sections: general information, catalog/ technical service personnel, other library personnel, all library personnel creating non-MARC metadata, position titles, standards and documentation, and comments. The survey also solicited information regarding digital projects see Appendix.

The first section requested demographic information and information about digital projects supported. Thirty-nine of the 46 responding libraries currently support digitization projects. Seven additional respondents are using only MARC metadata. Four of these seven libraries have plans for future projects involving non-MARC metadata. For example, the University of Wyoming plans to create non-MARC metadata for its institutional depository and for its "Wyoming Memory" portal. Another example is the University of California, Davis' plans to use EAD for a text encoding initiative project for eighteenth- and nineteenth-century poetry.

The highest number of digitization projects reported was 101, and the lowest was two. Six of the reporting libraries are supporting at least five digital projects. Twenty-five, or 64 percent, of the libraries are supporting ten or fewer projects. The following summaries provide an overview of selected questions.

Questions 6 and 10 were identical. Question 6 focused on responses from technical services personnel; question 10 elicited responses from personnel who worked elsewhere in the library. Table 1 provides an overview of these responses.

Advisory capacity was selected as the most frequent role for librarians who work both in technical services and non-technical services. The second most common roles for technical services librarians were maintenance and creation of non-MARC metadata. For technical services librarians, leadership was ranked third. Non-technical services librarians selected leadership and advisory equally, followed by non-MARC metadata creation. The paraprofessional's role in both technical services and 
TABLE 1. Non-MARC Metadata Personnel Roles

\begin{tabular}{lcrcrc}
\hline Variable & Creation & Leadership & Maintenance & Advisory & Other \\
\hline Cataloging/Technical Services & & & & & \\
$\quad$ Librarians & 27 & 21 & 27 & 34 & 6 \\
$\quad$ Paraprofessionals & 25 & 1 & 19 & 3 & 2 \\
$\quad \begin{array}{l}\text { Non-cataloging/ } \\
\text { Technical Services }\end{array}$ & & & & & \\
$\quad$ Librarians & 29 & 31 & 23 & 31 & 6 \\
$\quad$ Paraprofessionals & 29 & 4 & 23 & 7 & 5 \\
\hline
\end{tabular}

non-technical services was predominantly the creation and maintenance of non-MARC metadata.

Both the literature and the survey indicated that the paraprofessional has taken on the work that was once the domain of the catalog librarian. These findings correspond with Boydston and Leysen, who stated that at Iowa State University, non-MARC metadata creation has been added to the role of the catalog librarian, whereas the paraprofessional staff has assumed the monographic print cataloging. ${ }^{8}$ The authors of this survey suggest that this trend will continue as non-MARC metadata schemes proliferate.

Staffing issues were addressed by question 14. Participants could check more than one answer. Adding responsibility to existing positions was most often indicated. Realignment in work assignments was also indicated by the second and third most common responses, shifting existing staff and hiring new staff. Some libraries report handling staffing issues through grant funding, volunteers, student workers, and outsourcing, as seen in Table 2 .

Reporting libraries indicated that workshops, which were also categorized with Webinars, online tutorials, and courses, are the most frequently used training method. The second most frequent response was one-on-one interactions. Self-directed learning, such as reading and conference attendance, are reported less frequently. Several of the respondents indicated that an in-house expert was part of the existing personnel or was hired to oversee digital projects. Table 3 is an overview of survey question 15, "How was your staff trained in the creation and/or maintenance of non-MARC metadata?"

An interesting trend revealed in the survey was the naming of position titles. Ten libraries reported that at least one department name within the 
TABLE 2. Staffing Issues

\begin{tabular}{lccc}
\hline Added Responsibilities & Shifted & Hired & Other \\
\hline 35 & 25 & 22 & 5 \\
\hline
\end{tabular}

TABLE 3. Staff Training Issues

\begin{tabular}{lccc}
\hline Workshops & One-on-One & Self-Directed & Consultant \\
\hline 29 & 23 & 18 & 7 \\
\hline
\end{tabular}

library includes the word metadata. Five of those libraries have units called Cataloging and Metadata Services; two have units named Metadata Services. Twenty-two of the libraries indicated that the term metadata is included in position titles. The most common position titles are listed in Table 4.

Section six of the survey focused on standards and documentation. When asked what groups or positions ensure that metadata standards are followed, four respondents identified catalogers or cataloging departments as having the sole responsibility. Five university libraries reported that individuals and departments have this duty, but the responses made it unclear whether they were technical services related. For the majority of respondents, metadata standards are cooperatively maintained by several departments and/or individuals. Archives and Special Collections, Digital Initiatives, Technical Services, and System departments were the most commonly involved in this task.

Questions 8 and 12 address non-MARC metadata schemes used by cataloging/technical services personnel. Question 8 focused on responses from technical services personnel and question 12 sought responses from non-technical services personnel. For both groups, the survey results indicated Dublin Core as the most frequently used schema. EAD was second for both; it was more commonly used by non-technical services personnel. The authors believe that Dublin Core's popularity may result from its ease of use and lack of complex standards such as those of AACR2. The phenomenon of Dublin Core being the most popular schema is also documented and reported by the surveys of $\mathrm{Kim}^{9}$ and Polydoratou and Nicholas. ${ }^{10}$ In addition to the non-MARC metadata 
TABLE 4. Position Titles Using the Word Metadata

\begin{tabular}{lccc}
\hline $\begin{array}{l}\text { Metadata/Cataloger or } \\
\text { Cataloging/Metadata }\end{array}$ & $\begin{array}{l}\text { Metadata } \\
\text { Librarian }\end{array}$ & $\begin{array}{c}\text { Metadata } \\
\text { Coordinator }\end{array}$ & $\begin{array}{c}\text { Metadata } \\
\text { Specialist }\end{array}$ \\
\hline 10 & 8 & 4 & 4 \\
\hline
\end{tabular}

schemes listed in Table 5, libraries report using one or more alternative metadata schemes such as METS, MIX, LOM, and MADS.

\section{DISCUSSION AND RECOMMENDATIONS}

In the past, with the creation of MARC bibliographic records, catalog librarians had the primary responsibility for maintaining the library's catalog, and assumed a largely uncontested leadership role in terms of metadata creation. With the use of non-MARC metadata, these responsibilities are now distributed throughout the library, university, and digitization project communities. The catalog librarian's role has substantially changed to an advisory role as indicated in the survey. In addition, the role of advisor was the most frequently declared response for librarians from other parts of the library. The survey demonstrates that when assuming the role of advisor, librarians need to emphasis communication, collaboration, training, and the documentation and maintenance of standards.

In terms of communication, catalog librarians are in the best position to advocate the importance of metadata to the rest of the staff. Boydston and Leysen's article indicates catalog librarians have an extensive knowledge of working with bibliographic documentation and standards which are constantly in flux in today's digital world. ${ }^{11}$ The survey documents this expertise. For example, Brigham Young University stated, "Often the catalog librarians are involved in verifying that the metadata was completed correctly." The University of Manitoba added, "If the metadata is created by the content creators, the Electronic Resources Cataloguer may check or edit the metadata by adding controlled vocabulary, etc."

\section{Collaboration}

Although collaboration was not specifically addressed in the survey questions, open-ended responses gave a strong indication of its existence. The University of Tennessee has a metadata working group comprising 
TABLE 5. Metadata Schemes Used by Cataloging/Technical Services Personnel

\begin{tabular}{|c|c|c|c|c|c|c|}
\hline Dublin Core & EAD & GM/FGDC & MODS & ONIX & TEI & VRA \\
\hline \multicolumn{7}{|c|}{ Cataloging/Technical Services } \\
\hline 27 & 16 & 3 & 13 & 1 & 12 & 6 \\
\hline \multicolumn{7}{|c|}{ Non-Cataloging/Technical Services } \\
\hline 31 & 27 & 6 & 11 & 1 & 11 & 7 \\
\hline
\end{tabular}

library, archives, and museum representatives. Baylor University stated, "Our digital projects have a leadership group with the digitization projects unit with expertise being pulled in from other areas as needed. Projects are accomplished through integration of responsibilities and team work." At the University of Nebraska-Lincoln, the Center for Digital Research in the Humanities (CDRH), a joint initiative between the UNL Libraries and the College of Arts and Science exists. CDRH's projects frequently involve the creation of metadata and the use of common standards.

Collaboration is also apparent within metadata training. An example was a workshop presented by UNL Libraries and the United States Geological Survey (USGS). The Federal Geospatial Data Committee (FGDC) workshop on geospatial metadata standards was attended by all levels of library and non-library personnel. When developing the workshop, the fact that most of the attendees were non-library personnel, was taken into consideration. The workshop was designed to accommodate multiple levels of understanding. As suggested in Sue Kriegsman's article, "Cataloging Training for People Who Are Not Catalogers," the presenters took into consideration how the various organizations would be using the metadata and what their objectives were in creating the metadata. ${ }^{12}$ Emphasis was placed on the need for metadata and standards and the role libraries have in creating metadata. Library jargon was avoided. The presenters attempted to use terminology familiar to everyone. For example, they used the phrase metadata creation rather than cataloging.

\section{Maintaining Standards}

With the creation and maintenance of metadata distributed among different departments within the library, the university, and the digitization project community, it becomes imperative to have a centralized place where decisions involving standards are documented. The authors 
advocate that the libraries create a storehouse readily available to all members of the digital community as recommended by the UNL Libraries metadata taskforce committee. The storehouse should include all metadata documentation and implementation decisions. Stakeholders should actively maintain document changes. ${ }^{13}$

Another factor as to why it is important to maintain standards is that not all metadata is created manually. As noted by the respondent from Oregon State University, "In many cases, we map existing MARC data from our OPAC to Dublin Core as we digitize print materials from our collections. We also map metadata that has been maintained in other university units in the form of spreadsheets and databases." The authors believe that interoperability and the ability to harvest quality metadata should be a high priority. They stress the importance of keeping in mind that data is only as good as the original data.

\section{Recommendations}

The authors recommend that future studies address how users use metadata to access digital content and how their expectations differ from when they are searching the catalog for a resource. Expectations will vary among faculty members, undergraduates, and other users. Some resources may require detailed metadata; a resource that will be available for a short time may require little bibliographic information or none at all.

In conclusion, the overall finding of the survey indicates that the metadata creation and maintenance has been disseminated among librarians and paraprofessional staff who work in various departments.

Because of this redistribution of metadata work assignments, it is important that library professionals maintain a role of leadership in the creation and adherence of metadata standards, and continue to offer their expertise in an advisory role.

\section{REFERENCES}

1. U.S. Department of the Interior. U.S. Geological Survey. 2007. USGS CMG "Formal Metadata" Definition.: http://walrus.wr.usgs.gov/infobank/programs/html/ definition/fmeta.html (accessed Aug. 2, 2007).

2. Chu, Heting, Information representation and retrieval in the digital age. (Medford, New Jersey: Information Today, 2003) 3-4.

3. Lyman, P. \& Varian, H. R. "How much information," 2003.http://www2. sims.berkeley.edu/research/projects/how-much-info-2003/ (accessed July 20, 2007). 
4. Hall-Ellis, Sylvia D., Cataloging electronic resources and metadata: Employers' expectations as reflected in American Libraries and AutoCAT, 2000-2005. Journal of Education for Library and Information Science 47, no. 1 (2006): 48.

5. Hsieh-Yee, I., Cataloging and metadata education: Asserting a central role in information organization. Cataloging \& Classification Quarterly 34, no.1/2 (2002): 202.

6. Wilder, Stanley J., Demographic trends affecting professional technical services staffing in ARL libraries. Cataloging \& Classification Quarterly 34, no. 1/2 (2002): 52.

7. Boydston, Jeanne M. K., and Joan M. Leysen, Observations on the catalogers' role in descriptive metadata creation in academic libraries. Cataloging \& Classification Quarterly 43 (2006): 11.

8. Boydston and Leysen, "Observations on the catalogers'," 11.

9. Kim, Kyung-Sun, Recent work in cataloging and classification, 2000-2002. Library Resources \& Technical Services 47, no.3 (2003): 102.

10. Polydoratou, Panayiota \& Nicholas, David. 2001. Familiarity with and use of metadata formats and metadata registries amongst those working in diverse professional communities within the information sector. Aslib Proceedings 53, no.8 (September 2001): 315-317.

11. Boydston and Leysen, "Observations on the catalogers'," 8.

12. Kriegsman, Sue, Catalog training for people who are not catalogers: The Colorado Digitization Project experience. Cataloging \& Classification Quarterly 34, no.3 (2002): 371-372.

13. Mering, M., Childers, S., Fleming, A. et.al., White papers: University of Nebraska Lincoln, Report of task force on metadata analysis, http://digitalcommons. unl.edu/librarywhitepapers/1/ (accessed July 20, 2007).

Received for review: August 3, 2007 Accepted for publication: August 27, 2007 


\section{APPENDIX}

\section{SURVEY SAMPLE: METADATA WORKFLOW USAGE QUESTIONNAIRE}

Purpose: To investigate the workflow involved in the creation and maintenance of metadata used to describe electronic resources, such as digital image collections and GIS datasets at the University of Nebraska-Lincoln Libraries' peer institutions. The survey includes questions regarding training and staffing issues, level of staff, various projects, metadata standards and schemes, and library departments in which the metadata is created or maintained.

Important: The survey may take up to 30 minutes to complete. Individuals will not be identified in any way with the information obtained from the survey. You are under no obligation to participate in this study. Completion of this survey will be taken as evidence that you have read the information provided above, have voluntarily decided to participate, and have consented to have your responses included in the results. There is no obligation to answer all of the questions. You may choose to submit a partially completed survey. If you have any questions please feel free to contact Adonna Fleming at (402) 4723920 or email at dfleming2@unl.edu.

\section{General Information:}

1. What is the name of your institution?

2. Does your library only create MARC21 formatted metadata? __Yes No

2a. If yes, Do you have future plans for projects involving non-MARC metadata? Yes No

If yes, please describe:

If you answered 'yes' to question 2 the rest of the survey is non-applicable. However, we would appreciate you returning the survey.

3. How many digital projects is your library currently supporting?

4. How many of these projects are using non-MARC metadata?

5. What library departments/groups (including cataloging/technical services if applicable) are responsible for providing non-MARC metadata? Please list the departments/groups. 


\section{Cataloging/Technical Services Personnel:}

6. Please indicate which of the following roles apply to your cataloging/technical services librarian and paraprofessional personnel who work on non-MARC metadata.

\section{Librarians:}

Creation of non-MARC metadata

__Leadership (e.g., coordinating project)

_ Maintenance (e.g., make changes to existing non-MARC metadata)

Advisory (e.g., suggest field elements and values for the elements) Other

If you checked "Other", please explain:

\section{Paraprofessional staff:}

Creation of non-MARC metadata

Leadership (e.g., coordinating project)

Maintenance (e.g., make changes to existing non-MARC metadata

_Advisory (e.g., suggest field elements and values for the elements) Other

If you checked "Other", please explain:

7. The role of your cataloging/technical services personnel vary depending on Does the project and/or the metadata scheme? Yes No If yes, please explain.

8. What non-MARC metadata schemes are used by cataloging/technical services personnel? Dublin Core EAD GM / FGDC MODS _ ONIX TEI VRA Other If you checked "Other", please list:

9. How many FTE in the cataloging/technical services department work on non-MARC metadata?

Librarian or equivalent Paraprofessional

\section{Other Library Personnel:}

10. Please indicate which of the following roles apply to your non-cataloging/technical services personnel who work on non-MARC metadata. 


\section{APPENDIX (continued)}

\section{Librarians:}

_Creation of non-MARC metadata Leadership (e.g., coordinating project)

_ Maintenance (e.g., make changes to existing non-MARC metadata) Advisory (e.g., suggest field elements and values for the elements) Other

If you checked "Other", please explain:

\section{Paraprofessional staff:}

Creation of non-MARC metadata Leadership (e.g., coordinating project)

_ Maintenance (e.g., make changes to existing non-MARC metadata) Advisory (e.g., suggest field elements and values for the elements) Other

If you checked "Other", please explain:

11. Does the role of your non-cataloging/technical services personnel vary depending on the project and/or the metadata scheme? _ Yes No If yes, please explain.

12. What non-MARC metadata schemes are used by non-cataloging/technical services personnel? Dublin Core EAD GM / FGDC If MODS _ONIX _ _ TEI _VRA__ Other If you checked "Other", please explain:

13. How many FTE in the non-cataloging/technical services department work on non-MARC metadata?

_L Librarian or equivalent Paraprofessional

\section{All Library Personnel creating non-MARC metadata:}

14. How are staffing issues addressed? (Check all that apply)

Shifted existing staff to new job lines Hired new staff for new job lines Added responsibilities to existing job Other If you checked "Other" please explain: 
15. How was your staff trained in the creation and/or maintenance of non-MARC metadata? (e.g. one-on-one, consultant, workshop)

\section{Position Titles:}

16. Do you have a department or section whose name includes the word metadata? Yes No

If yes, please provide the title/s.

17. Do you have a position whose name includes the word metadata? Yes _ No

If yes please provide the title/s.

\section{Standards and Documentation:}

18. What groups or positions in library oversee that metadata standards are followed?

19. How do the above groups or positions document their decisions?

\section{Comments:}

